\title{
Fungal Trunk Pathogens Associated With Juglans regia in the Czech Republic
}

\author{
A. Eichmeier, ${ }^{1, \dagger}$ J. Pecenka, ${ }^{1}$ M. Spetik, ${ }^{1}$ T. Necas, ${ }^{2}$ I. Ondrasek, ${ }^{2}$ J. Armengol, ${ }^{3}$ M. León, ${ }^{3}$ C. Berlanas, ${ }^{4}$ and D. Gramaje ${ }^{4}$ \\ ${ }^{1}$ Mendeleum Institute of Genetics, Faculty of Horticulture, Mendel University in Brno, 69144 Lednice, Czech Republic \\ ${ }^{2}$ Department of Fruit Growing, Faculty of Horticulture, Mendel University in Brno, 69144 Lednice, Czech Republic \\ ${ }^{3}$ Instituto Agroforestal Mediterráneo, Universitat Politècnica de València, 46022 Valencia, Spain \\ ${ }^{4}$ Instituto de Ciencias de la Vid y del Vino, Consejo Superior de Investigaciones Científicas, Universidad de la Rioja, Gobierno de \\ La Rioja, 26007 Logroño, Spain
}

\begin{abstract}
Juglans regia L. (English walnut) trees with cankers and dieback symptoms were observed in two regions in the Czech Republic. Isolations were made from diseased branches. In total, 138 fungal isolates representing 10 fungal species were obtained from wood samples and identified based on morphological characteristics and molecular methods:

Pathogenicity tests conducted under field conditions with all species using the mycelium-plug method indicated that Eutypa lata and Cadophora spp. were highly virulent to woody stems of walnut. This is the first study to detect and identify fungal trunk pathogens associated with diseased walnut trees in Europe.
\end{abstract} Cadophora novi-eboraci, Cadophora spadicis, Cryptovalsa ampelina, Diaporthe eres, Diplodia seriata, Dothiorella omnivora, Eutypa lata, Eutypella sp., Peroneutypa scoparia, and Phaeoacremonium sicilianum.
Keywords: Botryosphaeriaceae, Cadophora, Diaporthe, Diatrypaceae, phylogenetic analysis, sequencing, trunk pathogens, walnut trees
Juglans regia L. (English walnut) originated in Central Asia and is the most important walnut species. This tree is grown for its seed, which is a great source of nutrients, especially essential fatty acids and proteins (Badenes and Byrne 2012). The world production of walnut seed accounted for 3.7 million tons in 2016, with China being the world's largest producer (1.78 million tons) followed by the United States $(607,814$ tons) and Iran (405,281 tons) (FAO 2018). Walnut seed production in the Czech Republic is still in its infancy and presently occupies 175 ha and yielded 91 tons in 2016 (FAO 2018). Approximately $80 \%$ of walnuts are estimated to grow in yards and close to village buildings, $18.8 \%$ in tree avenues, and only $1.2 \%$ in commercial orchards in the Czech Republic (Avanzato et al. 2014).

In the past 10 years, cankers and dieback symptoms such as leaf chlorosis, dead branches, and bud and shoot dieback have become frequent on walnut trees in the Czech Republic. Internal wood symptoms on affected trees range from black spots or circular discoloration of the xylem vessels to wedge-shaped necrosis. These symptoms are characteristic of trunk disease pathogens, which have been reported on grapevine and fruit trees worldwide (Gramaje et al. 2016). These fungi primarily invade woody hosts through openings such as sucker wounds (Makatini 2014) or pruning wounds (English and Davis 1978; van Niekerk et al. 2011). Fungal trunk pathogen spores are aerially dispersed, but arthropods were also found to carry them in vineyards (Moyo et al. 2014). The abnormalities caused by these pathogens lead to lower quality of fruits and reduced yield, which ultimately affects the amount of income for growers.

${ }^{\dagger}$ Corresponding author: A. Eichmeier; ales.eichmeier@mendelu.cz

Funding: This work was supported by the Ministerstvo Školství, Mládeže a Tělovýchovy (EFRR "Multidisciplinary Research to Increase Application Potential of Nanomaterials in Agricultural Practice," project CZ.02.1.01/0.0/0.0/ 16_025/0007314). This research was also supported by the Technologická Agentura České Republiky (project TJ02000096).

*The $\boldsymbol{e}$-Xtra logo stands for "electronic extra" and indicates that two supplementary tables are published online.

The author(s) declare no conflict of interest.

Accepted for publication 3 October 2019.

(C) 2020 The American Phytopathological Society
Research has revealed that walnut represents a rich catch crop for several fungal trunk pathogens. Species belonging to the families Botryosphaeriaceae (Agustí-Brisach et al. 2019; Chen et al. 2013, 2014; Dervis et al. 2019; Díaz et al. 2018; Inderbitzin et al. 2010; Li et al. 2015; Linaldeddu et al. 2016; Zhang et al. 2017), Diaporthaceae (Agustí-Brisach et al. 2019; Chen et al. 2014; Fan et al. 2018; Meng et al. 2018), and the genera Cytospora (Fan et al. 2015; Zhao et al. 2018) and Phaeoacremonium (Spies et al. 2018) have been reported on walnut trees.

Although many fungal species belonging to a number of genera are well-recognized pathogens of walnut trees, the etiology of the severe decline of walnut trees in the Czech Republic is still unknown. Therefore, the aim of this study was to identify fungal trunk pathogens associated with wood necrosis of English walnut in the Czech Republic and to evaluate their status as pathogens on this host by conducting pathogenicity tests under field conditions.

\section{Materials and Methods}

Sampling and collection of fungal isolates. In 2016, field surveys were conducted in six localities in the Moravia region: namely, Rajhrad, Pouzdřany, Boleradice, and Perná in South Moravia and Choryně and Lešná in the Moravian-Silesian region (Fig. 1). Symptomatic wood from branches and shoots showing cankers and dieback were collected from six walnut orchards (one orchard per locality), aged between 30 and 40 years. In each orchard, 10 symptomatic branches were collected from 10 different trees, taken to the laboratory, and processed as follows. Branches were debarked and transversely cut to $1-\mathrm{cm}$ chips. These wood fragments were first surface-sterilized in $75 \%$ ethanol for $1 \mathrm{~min}$ followed by flaming. From each wood fragment, five pieces of approximately $2 \times 2 \mathrm{~mm}$ were plated on malt extract agar (MEA) (Sigma-Aldrich Laboratories, St. Louis, MO) supplemented with 0.5 g/liter of streptomycin sulfate (MEAS) (Biosynth, Staad, Switzerland). A total of five plates were used per wood sample, 25 pieces in total. Plates were incubated at $25^{\circ} \mathrm{C}$ in the dark for up to 4 weeks. To prevent the overgrowing of fast-spreading mycelia, the plates were checked every day and growing mycelia of potential fungal pathogens were transferred to potato dextrose agar (PDA) (HiMedia, Einhausen, Germany) plates for further identification and characterization. Pure cultures of hyphal tipped or single spore isolates were maintained in the culture collection of the Mendeleum Institute of Genetics. 
Morphological identification of fungal isolates. All fungal isolates were initially characterized and classified on the basis of their cultural appearance on PDA and microscopic structures. Species of Botryosphaeriaceae, Diaporthaceae, and Diatrypaceae families were identified based on colony morphology, colony color and growth, and conidial color and shape according to Phillips et al. (2013), Marin-Felix et al. (2019), and Dissanayake et al. (2017), respectively. To enhance sporulation, six mycelial plugs $(5-\mathrm{mm}$ diameter) of each Botryosphaeriaceae and Diaporthaceae isolate were placed in plates containing $2 \%$ water agar (Merck, Kenilworth, NJ) supplemented with sterilized pine needles. Plates of each isolate were incubated under continuous light at $24^{\circ} \mathrm{C}$ until pycnidia were produced on the pine needles. Culture characteristics and pigment production on PDA, MEA (Merck), and oatmeal agar (30 $\mathrm{g}$ of oatmeal and $15 \mathrm{~g}$ of agar; Merck) and the main microscopic structures (phialide type and shape, conidiophore morphology and hyphal wart size, and conidial shape and size) from aerial mycelium were used to identify of Phaeoacremonium isolates (Marin-Felix et al. 2019). The main morphological characteristics such as conidiophore, phialide, collarettes, and conidial morphology were used to identify Cadophora isolates (Harrington and McNew 2003). All of the main microscopic structures were mounted on glass microscope slides and studied in more detail under a digital microscope (VHX-6000; Keyence, Osaka, Japan).

DNA isolation, PCR amplification, and sequencing. For each isolate, $50 \mathrm{mg}$ of fungal mycelium was scraped from the culture surface and mechanically disrupted by grinding to a fine powder under liquid nitrogen using a mortar and pestle. Total DNA was extracted using a NucleoSpin Tissue DNA extraction kit (Macherey-Nagel, Düren, Germany) following the manufacturer's instructions. The internal transcribed spacers (ITS1 and ITS2) including the 5.8S ribosomal RNA gene were amplified to identify all fungal trunk pathogen isolates. For the Botryosphaeriaceae spp., a partial sequence of translation elongation factor 1- $\alpha$ (tefl) was also amplified and sequenced to confirm species identity. The ITS region and tefl gene were amplified using primer pairs ITS1/ITS4 (White et al. 1990) and EF1-688F/EF1-1251R (Alves et al. 2008), respectively. For the Diaporthe spp., a multilocus identification was used based on five genomic loci (ITS, tef1, calmodulin [cal], histone H3 [his3], and partial $\beta$-tubulin [tub2]) (Guarnaccia et al. 2018). The primers
EF1-728F/EF1-986R and CAL-228F/CAL-737R (Carbone and Kohn 1999) were used to amplify part of the tefl and cal genes, respectively. The $t u b 2$ region was amplified using the primers Bt2a/ Bt2b (Glass and Donaldson 1995), and the his3 region was amplified using the primers CYLH3F/H3-1b (Crous et al. 2004; Glass and Donaldson 1995). The Phaeoacremonium spp. were also identified by sequence analysis of $t u b 2$ and actin (act) genes, using the primer pairs T1 (O'Donnell and Cigelnik 1997) and Bt2b (Glass and Donaldson 1995) and ACT-512F/ACT-783R (Carbone and Kohn 1999). The Cadophora spp. were confirmed by sequence analysis of the tub2 and tefl genes using the primer pairs BTCadF/ BTCadR (Travadon et al. 2015) and EF1-728F/EF1-986R (Carbone and Kohn 1999). For the Diatrypaceae spp., the ITS region was amplified using primer pairs ITS1/ITS4 (White et al. 1990). PCR was performed utilizing G2 Flexi DNA polymerase (Promega, Madison, WI) with primers targeting the mentioned gene sequences using respective amplification conditions according to the authors of the primers. PCR amplicons were sequenced as described in Eichmeier et al. (2010). Fungal species were initially identified using the NCBI MegaBLAST algorithm (https://www.ncbi.nlm. nih.gov).

Phylogenetic analyses. Fungal sequences from walnuts from the Czech Republic were aligned with available sequences in GenBank/NCBI, including ex-type specimens from several hosts for comparison using the MAFFT sequence alignment program version 6 (Katoh and Toh 2008) (Supplementary Table S1). Alignments were inspected in Sequence Alignment Editor version 2.0a11 (Rambaut 2002). Phylogenetic analyses were performed in MEGA version 6 (Tamura et al. 2013) for groups of fungi with more than one fungal species. The maximum likelihood (ML) estimation was applied on six separate data sets of the fungal families Botryosphaeriaceae (ITS and tefl) and Diatrypaceae (ITS) and the genus Cadophora (ITS, tub2, and tef1). All resulting tree topologies (data not shown) were visually compared for congruence to combine two Botryosphaeriaceae data sets (ITS and tef1) and three Cadophora data sets (ITS, tub2, and tef1) for multilocus analyses. ML analyses were performed in MEGA using the best-fit model as estimated with the Bayesian information criterion (BIC) in jModelTest 2.1.10 (Darriba et al. 2012). Branch support was calculated from 1,000 bootstrap replicates for the single and concatenated data sets.

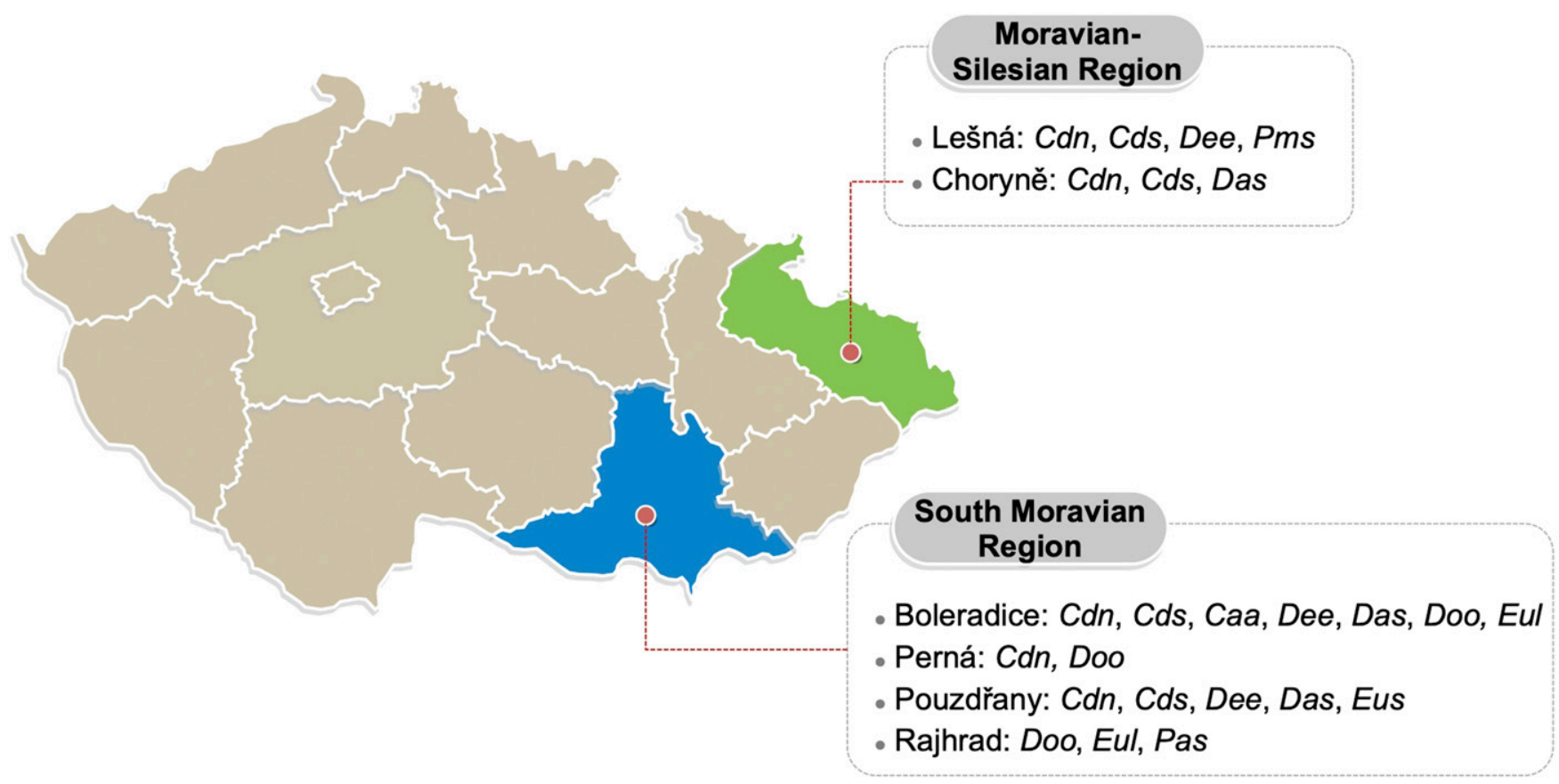

Fig. 1. Czech Republic map indicating the fungal species detected in each region surveyed. Cdn $=$ Cadophora novi-eboraci, Cds $=$ Cadophora spadicis, Dee $=$ Diaporthe eres $P m s=$ Phaeoacremonium sicilianum, Das $=$ Diplodia seriata, Caa $=$ Cryptovalsa ampelina, Doo = Dothiorella omnivora, Eul $=$ Eutypa lata, Eus $=$ Eutypella sp., and Pas $=$ Peroneutypa scoparia. 
The ITS sequence of Xylaria hypoxylon (CBS 122620) was used as an outgroup in phylogenetic analysis of Diatrypaceae, whereas the ITS and tef sequences of Botryosphaeria dothidea (CMW8000) and Neoscytalidium dimidiatum (CBS 499.66), respectively, were used as outgroups in Botryosphaeriaceae. For Cadophora spp., sequences of Cadophora finlandica (CBS 44486) served as the outgroup taxon. Representative sequences of fungal trunk disease isolates derived in this study were deposited in GenBank/NCBI (Table 1) and the alignments in TreeBASE under the study numbers 24575 (Botryosphaeriaceae spp. and Diatrypaceae spp.) and 24491 (Cadophora spp.) (https://treebase.org).

Pathogenicity tests. One isolate of each of the following species was used in the field pathogenicity test: Diplodia seriata, Dothiorella omnivora, Eutypella sp., Eutypa lata, Cryptovalsa ampelina, Diaporthe eres, Cadophora novi-eboraci, Cadophora spadicis, Peroneutypa scoparia, and Phaeoacremonium sicilianum (Supplementary Table S2). In April 2017, healthy 1-year-old dormant grafted seedlings of walnut trees (Apollo cultivar grafted onto J. regia L. rootstock) were obtained from a commercial nursery and planted in rows spaced $0.4 \mathrm{~m}$ apart, with an in-row spacing of $0.5 \mathrm{~m}$. Wounds were made on the woody stems of the walnut trees using a 6-mm cork borer. Agar plugs $6 \mathrm{~mm}$ in diameter were taken from the margin of a growing colony on PDA (7 to 20 days old), placed into the fresh wound and immediately covered by moist cotton, and wrapped with parafilm and aluminum foil to prevent desiccation. Experiments were laid down following a completely randomized design with seven replications for each fungal isolate. In addition, seven plants were wounded and inoculated in a similar manner with sterile PDA plugs, to serve as controls. The experiment was repeated twice. Lengths of wood lesions induced by inoculated isolates were evaluated 6 months after inoculation. The extent of vascular discoloration was measured upward and downward from the inoculation point. Fungal reisolations were carried out from the edges of lesions on MEAS, and fungi were identified as described previously fulfilling Koch's postulates.

Statistical analysis. Homogeneity of variance across treatments was evaluated using the Levene test (Box et al. 1978). To meet parametric assumptions, a square root transformation to total lesion length was applied. Lesion length was then analyzed using the analysis of variance. Data from all experiments were analyzed using Statistix 10 software (Analytical Software, Tallahassee, FL).
Transformed data means were compared using Tukey's honestly significant difference test at $P=0.05$.

\section{Results}

Sampling and collection of fungal isolates. Both internal and external disease symptoms were observed on the surveyed trees and included cankers on trunks and branches and branch dieback (Fig. 2). The most common symptoms in cross-sections were wedge-shaped necrosis, irregular wood necrosis, central necrosis, and black spots (Fig. 2).

Based on colony morphology, phylogenetic analyses, and conidial characteristics (see below), 138 fungal isolates belonging to five families were recovered from English walnut (Supplementary Table S2). One species of the Togniniaceae family (Phaeoacremonium sicilianum), two species of the Botryosphaeriaceae family (Diplodia seriata and Dothiorella omnivora), four species of the Diatrypaceae family (Cryptovalsa ampelina, Eutypa lata, Peroneutypa scoparia, and Eutypella sp.), one species of the Diaporthaceae family (Diaporthe eres), and two species of the genus Cadophora (Cadophora novi-eboraci and Cadophora spadicis) were isolated from symptomatic branches of walnut trees. Species of Cadophora (66.7\%) were the prevalent fungi associated with wood symptoms from which isolations were made, followed by species in families Diatrypaceae and Botryosphaeriaceae, both with $14.5 \%$ of the fungi isolated. In general, there was not a regional effect on fungal distribution (Fig. 1), but species of Diatrypaceae were only found in the South Moravian region, which is $1.2^{\circ} \mathrm{C}$ warmer on average than the MoravianSilesian region (http://portal.chmi.cz/historicka-data/pocasi/uzemniteploty\#).

Fungal trunk pathogens were isolated in 34 of the 60 samples $(56.7 \%)$ collected (Table 2). More than one fungal species was isolated from a single sample in 11 of the 34 samples $(32.3 \%)$ that tested positive for fungal trunk pathogens. Most of the fungal isolates were recovered from black spots $(42.0 \%)$ and central necrosis $(34.1 \%)$ (Table 3). The black discoloration of the xylem vessels and central necrosis were mostly colonized by Cadophora spp., with 96.5 and $68.1 \%$ of the total number of isolates, respectively. The irregular wood necrosis was mostly colonized by Botryosphaeriaceae spp. (56.2\%), followed by Cadophora novi-eboraci (25\%). The wedgeshaped wood necrosis was mostly colonized by Diatrypaceae spp. (72.2\%), followed by Dothiorella omnivora (27.8\%).

Table 1. Origin and GenBank accession numbers of trunk disease fungal isolates obtained from walnut (used in the phylogenetic studies)

\begin{tabular}{|c|c|c|c|c|c|}
\hline \multirow[b]{2}{*}{ Species } & \multirow[b]{2}{*}{ Code } & \multirow[b]{2}{*}{ Locality } & \multicolumn{3}{|c|}{ GenBank accession number ${ }^{\mathrm{z}}$} \\
\hline & & & ITS & BT & TEF \\
\hline Cadophora novi-eboraci & OCR1 & Pouzdřany & MK431098 & MK431099 & MK993408 \\
\hline Cadophora novi-eboraci & OCR7 & Lešná & MK431101 & MK431102 & MK993409 \\
\hline Cadophora novi-eboraci & OCR12 & Lešná & MK431103 & MK431104 & MK993410 \\
\hline Cadophora spadicis & OCR32 & Lešná & MK431118 & MK431119 & MK993411 \\
\hline Cadophora spadicis & OCR36 & Pouzdřany & MK431106 & MK993414 & MK993412 \\
\hline Cadophora spadicis & OCR38 & Boleradice & MK993416 & MK993415 & MK993413 \\
\hline Cryptovalsa ampelina & OCR93 & Boleradice & MK431120 & - & - \\
\hline Cryptovalsa ampelina & OCR94 & Boleradice & MK993417 & - & - \\
\hline Diplodia seriata & OCR 120 & Boleradice & MK431136 & - & MK431137 \\
\hline Diplodia seriata & OCR 123 & Pouzdřany & MK993418 & - & MK431135 \\
\hline Diplodia seriata & OCR124 & Choryně & MK993419 & - & MK431138 \\
\hline Dothiorella omnivora & OCR127 & Boleradice & MK431141 & - & MK431142 \\
\hline Dothiorella omnivora & OCR 128 & Rajhrad & MK431139 & - & MK431140 \\
\hline Dothiorella omnivora & OCR129 & Boleradice & MK431143 & - & MK431144 \\
\hline Eutypa lata & OCR142 & Boleradice & MK431147 & - & - \\
\hline Eutypa lata & OCR149 & Rajhrad & MK431146 & - & - \\
\hline Eutypa lata & OCR 150 & Rajhrad & MK993420 & - & - \\
\hline Peroneutypa scoparia & OCR 155 & Rajhrad & MK431149 & - & - \\
\hline Peroneutypa scoparia & OCR 156 & Rajhrad & MK993421 & - & - \\
\hline Peroneutypa scoparia & OCR157 & Rajhrad & MK993422 & - & - \\
\hline Eutypella sp. & OCR159 & Pouzdřany & MK431148 & - & - \\
\hline
\end{tabular}

${ }^{\mathrm{z}}$ ITS $=$ internal transcribed spacer, $\mathrm{BT}=\beta$-tubulin, and TEF $=$ translation elongation factor $1-\alpha$. Dashes indicate sequences not available. 
Morphological identification and characterization of fungal isolates. Based on morphological criteria (microscopic and culture characterization), the fungal isolates obtained from walnut were classified into Cadophora, Diaporthe, Diplodia, Dothiorella, and Phaeoacremonium genera and several genera belonging to the Diatrypaceae family. Two isolates were characterized by pale brown to brown, flat, slow-growing cultures on PDA and MEA, abundant sporulation, and aseptate and hyaline conidia. Septate hyphae were fasciculate or single. Three types of phialides, variable in shape and size, were observed in these fungal isolates. These morphological characteristics corresponded to the genus Phaeoacremonium (Marin-Felix et al. 2019).

Twenty isolates formed white, dark green, or gray fast-growing colonies on PDA. These isolates also produced globose and black pycnidia on pine needles after 25 days. Conidia were hyaline or pigmented. All morphological and cultural characteristics corresponded to the Botryosphaeriaceae family (Phillips et al. 2013). At the genus level, isolates were assigned to two genera: Diplodia and Dothiorella.

Twenty-four isolates were characterized by having white-cream cottony slow-growing mycelium on PDA, lacking fruiting structures after an incubation time of 3 to 4 weeks in the dark. After 4 weeks under continuous fluorescent light, small black pycnidia were formed on the agar. Conidia developing in the fruiting bodies were hyaline and slightly curved, which corresponds to descriptions of species in the Diatrypaceae family (Glawe and Rogers 1984).

Five isolates were characterized by having white, cottony, slowgrowing mycelium. Dark brown or black, eustromatic pycnidia released a mucilaginous cream drop containing the two characteristic spore type: alpha and beta conidia. These morphological characteristics were similar to those described for Diaporthe species (MarinFelix et al. 2019). Ninety-two isolates formed white to pale yellow or vinaceous buff, felty, flat colonies on PDA. Conidia were elongate or ellipsoid. Prominent flask-shaped phialides and collarettes were frequently observed. Morphological and cultural characteristics of these isolates resembled those of Cadophora spp. (Harrington and McNew 2003; Travadon et al. 2015).

Molecular characterization and phylogenetic analyses. The BIC best-fit nucleotide substitution model identified by jModelTest was the Hasegawa-Kishino-Yano model with gamma distributed with invariant sites rates $(\mathrm{G}+\mathrm{I})$ for the Cadophora multilocus analysis. Alignment of 25 Cadophora sequences resulted in a 1,260-character data set. Three isolates clustered strongly (100\%) with the type specimen of Cadophora spadicis (CBS 111743), and three isolates were identified as Cadophora novi-eboraci (100\%, isolate NYC13) (Fig. 3).

Table 2. The diversity of trunk disease pathogens isolated from wood samples collected from Juglans regia orchards in the Czech Republic

\begin{tabular}{lc}
\hline Pathogen isolated & Samples $(\boldsymbol{n})$ \\
\hline Cadophora novi-eboraci & 2 \\
Cadophora spadicis & 9 \\
Diaporthe eres & 2 \\
Diplodia seriata & 4 \\
Dothiorella omnivora & 3 \\
Eutypa lata & 2 \\
Peroneutypa scoparia & 1 \\
Cadophora novi-eboraci + & 5 \\
$\quad$ Cadophora spacidis & \\
Cadophora novi-eboraci + & 1 \\
$\quad$ Phaeoacremonium sicilianum & \\
Cadophora spadicis + Eutypella sp. & 1 \\
Cadophora spadicis + Dothiorella omnivora & 2 \\
Diplodia spadicis + Dothiorella omnivora & 1 \\
Cadophora novi-eboraci + Cryptovalsa & 1 \\
ampelina + Diaporthe eres & \\
Total number of samples tested positive to & \\
trunk disease fungi & 34 \\
\hline
\end{tabular}
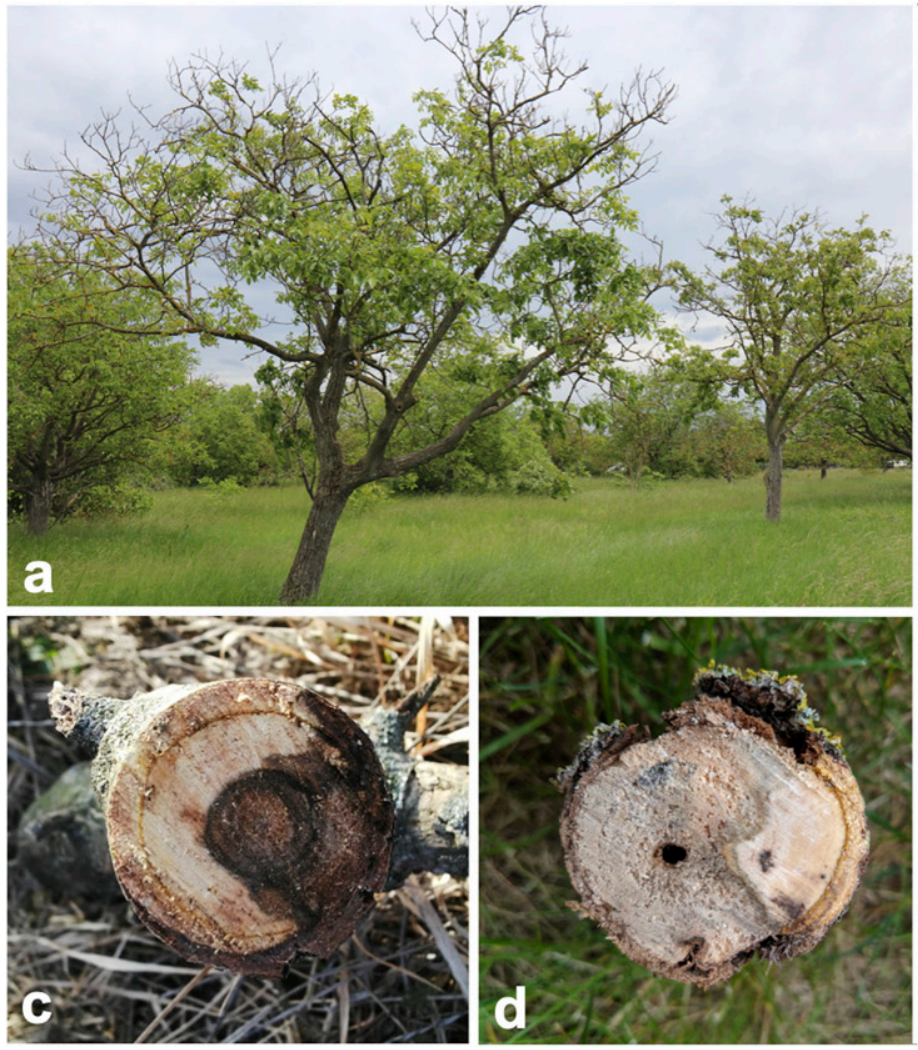
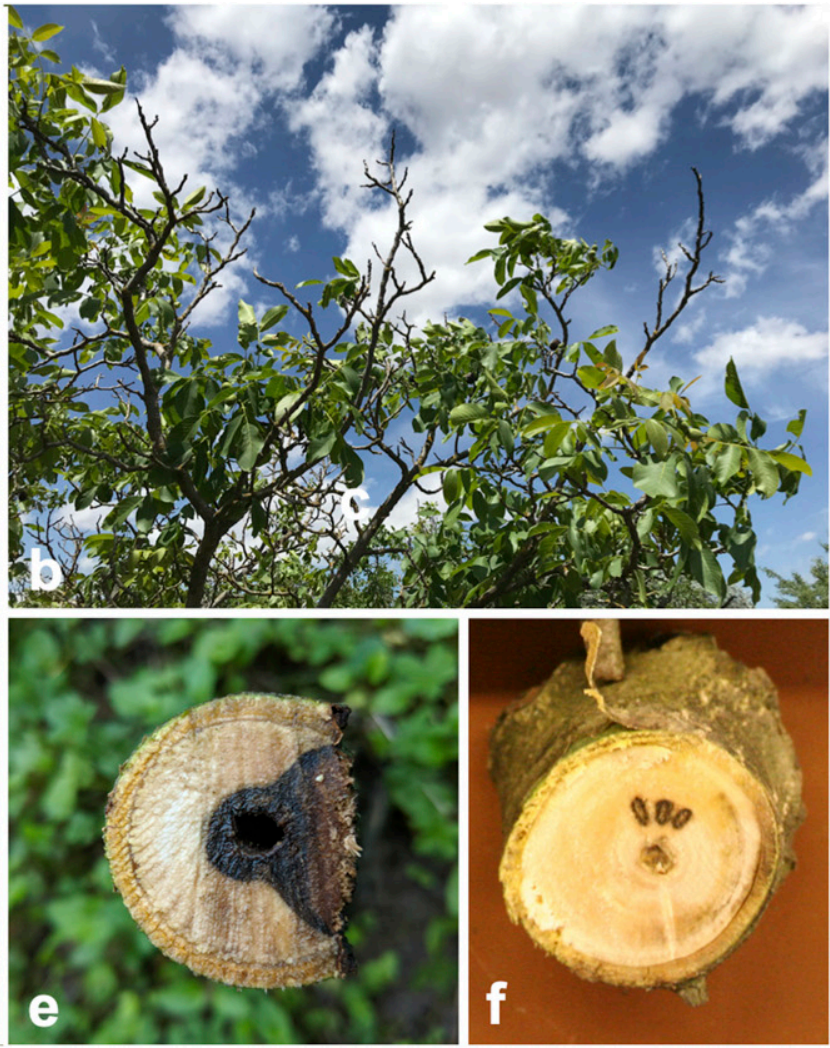

Fig. 2. Disease symptoms associated with fungal trunk pathogens on walnut trees in the Czech Republic. a and b, Dieback and wilting of branches. $\mathbf{c}$, $\mathbf{d}$, e, and $\mathbf{f}$, Internal symptoms visible when transversal and longitudinal cuts were made in branches used for fungal isolation: central and irregular necrosis (c, d, and e) and black spots (f). 
The ITS sequences of the nine representative diatrypaceous isolates from walnut were aligned with 29 reference strains and the outgroup. The selection of the reference strains was based on the phylogenetic closeness with the walnut isolates and the clade classification of Senwanna et al. (2017): there were 10 strains from clade $\mathrm{H}$
(Eutypella sensu lato), six from clade D (Eutypa sensu stricto), nine from clade I (genus Peroneutypa), and two from each of the clades L and M (Cryptovalsa sensu lato and genus Quaternaria, respectively). The resulting alignment consisted of 588 characters including gaps and the ML analysis was performed using the Kimura

Table 3. Number of isolates, locality, and disease symptoms associated with trunk disease fungi isolated from Juglans regia

\begin{tabular}{|c|c|c|c|c|c|c|c|}
\hline \multirow[b]{3}{*}{ Isolate family } & \multirow[b]{3}{*}{ Species } & \multirow[b]{3}{*}{ Locality } & \multicolumn{5}{|c|}{ Isolates $(n)$} \\
\hline & & & \multirow[b]{2}{*}{ Total } & \multicolumn{4}{|c|}{ Internal wood lesion type ${ }^{z}$} \\
\hline & & & & BS & $\mathrm{CN}$ & IWN & WSN \\
\hline \multirow[t]{4}{*}{ Diatrypaceae } & Cryptovalsa ampelina & Boleradice & 2 & - & 1 & - & 1 \\
\hline & Eutypa lata & Boleradice, Rajhrad & 13 & - & 4 & - & 9 \\
\hline & Peroneutypa scoparia & Rajhrad & 4 & - & 1 & 1 & 2 \\
\hline & Eutypella sp. & Pouzdřany & 1 & - & - & - & 1 \\
\hline Diaporthaceae & Diaporthe eres & Lešná, Boleradice, Pouzdřany & 4 & - & 2 & 2 & - \\
\hline \multirow[t]{2}{*}{ Botryosphaeriaceae } & Diplodia seriata & Boleradice, Pouzdřany, Choryně & 7 & - & 2 & 5 & - \\
\hline & Dothiorella omnivora & Boleradice, Perná & 13 & - & 4 & 4 & 5 \\
\hline Togniniaceae & Phaeoacremonium sicilianum & Lešná & 2 & 2 & - & - & - \\
\hline \multirow[t]{2}{*}{ Incertae sedis } & Cadophora novi-eboraci & Pouzdřany, Boleradice, Choryně, Lešná, Perná & 31 & 17 & 10 & 4 & - \\
\hline & Cadophora spadicis & Pouzdřany, Boleradice, Choryně, Lešná, Perná & 61 & 39 & 22 & - & - \\
\hline Total & & & 138 & 58 & 47 & 16 & - \\
\hline
\end{tabular}

$\mathrm{z}$ Various internal wood lesion types from which isolates were collected in a cross-section of affected wood samples: $\mathrm{BS}=$ black spot, $\mathrm{CN}=$ central necrosis, IWN = irregular wood necrosis, and WSN = wedge-shaped necrosis. Dashes indicate symptoms not available.

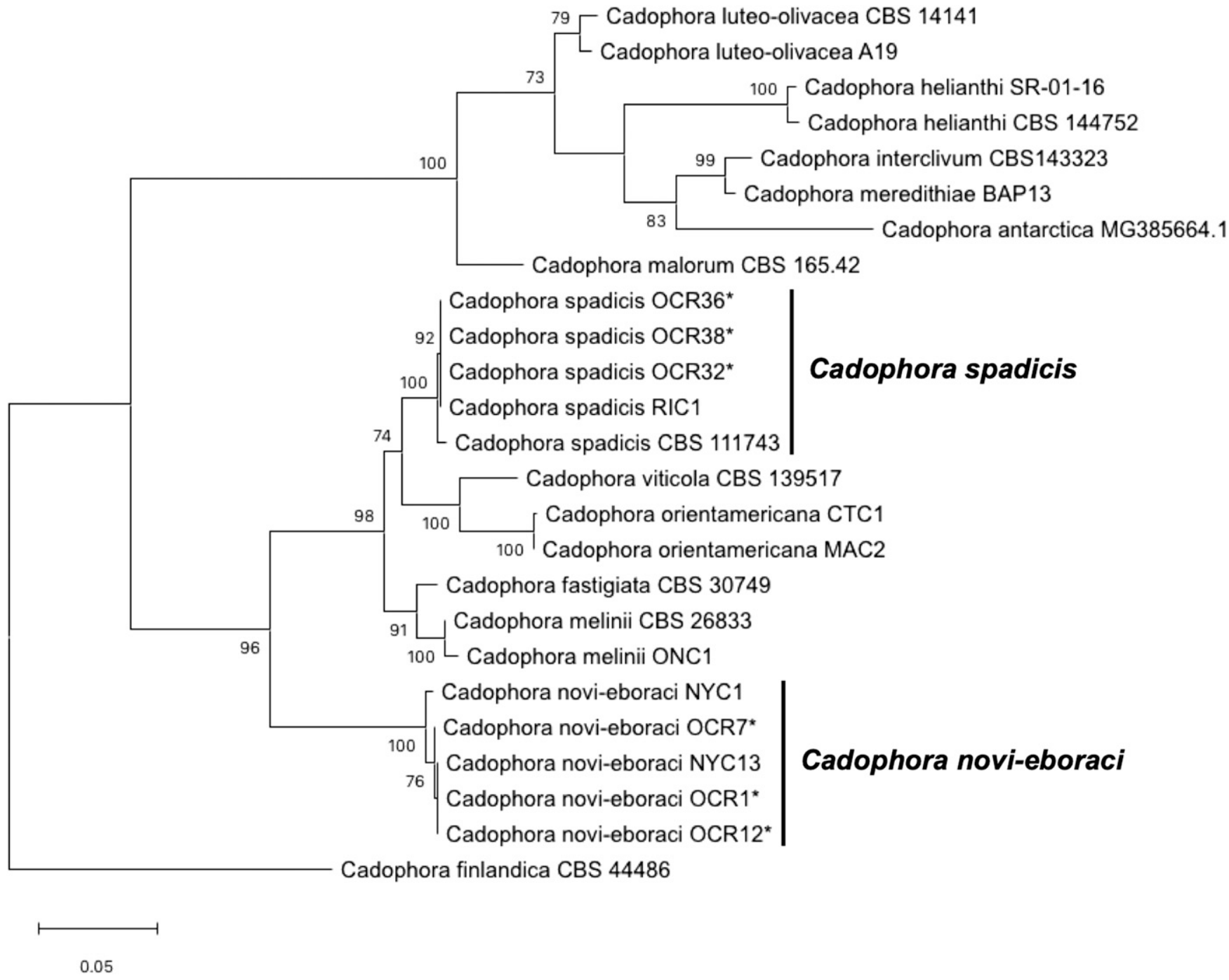

Fig. 3. Maximum likelihood phylogeny of Cadophora spp. as estimated from concatenated alignments of a three-gene data set (internal transcribed spacer, partial $\beta$-tubulin, and translation elongation factor 1- $\alpha$ ). Maximum likelihood bootstrap percentages are indicated at the nodes. Support values $<70 \%$ bootstrap are omitted. The scale bar indicates 0.05 expected changes per site. Fungal species isolated in this study are indicated with an asterisk. 
2-parameter model with gamma distribution. The walnut isolates clustered with high support with the reference sequences of Cryptovalsa ampelina (isolates OCR93 and OCR94; bootstrap 98\%), Eutypa lata (isolates OCR142, OCR149, and OCR150; bootstrap 98\%), Eutypella sp. (isolate OCR159; bootstrap 100\%), and Peroneutypa scoparia (isolates OCR155, OCR156, and OCR157; bootstrap 97\%) (Fig. 4).
The ITS and tef sequences of six botryosphaeriaceous isolates were aligned with 10 and nine reference strains of Diplodia and Dothiorella, respectively, and the outgroups. The multilocus alignment consisted of 772 characters including gaps (470 from ITS and 302 from $t e f$ ), and the Tamura 3-parameter model, with gamma distribution, was used for ML analysis. Isolates OCR127, OCR128, and OCR129 clustered with the Dothiorella omnivora reference

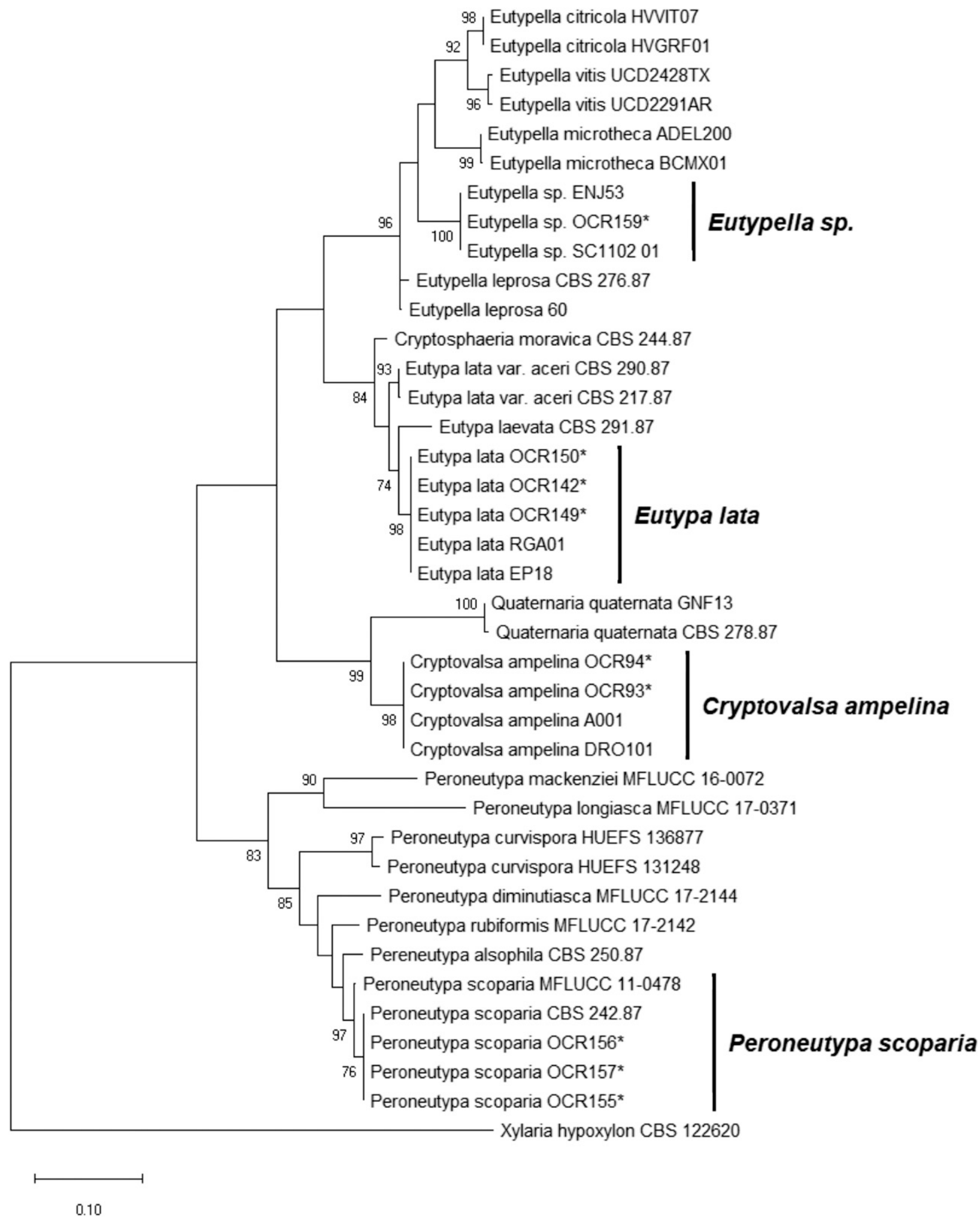

Fig. 4. Maximum likelihood phylogeny of Diatrypaceae spp. as estimated from concatenated alignments of a single gene data set (internal transcribed spacer). Maximum likelihood bootstrap percentages are indicated at the nodes. Support values $<70 \%$ bootstrap are omitted. The scale bar indicates 0.10 expected changes per site. Fungal species isolated in this study are indicated with an asterisk. 
strains with $95 \%$ bootstrap support, whereas isolates OCR120, OCR123, and OCR124 clustered with the reference strains of Diplodia seriata with $88 \%$ support (Fig. 5).

Two isolates, OCR 160 (tub2 accession MN013372 and act accession MN013374) and OCR 161 (tub2 accession MN013373 and act accession MN013375) clustered (98\%) with sequences of the ex-type of Phaeoacremonium sicilianum (CBS 123034). Two isolates, OCR 95 (ITS accession MK431127, tef1 accession MK468701, cal accession MK431128, his3 accession MK468702, and tub2 accession MK431127) and OCR 96 (ITS accession MK431121, tefl accession MN052813, cal accession MN052814, his3 accession MN017709, and $t u b 2$ accession MN017710) clustered (99\%) with sequences of the ex-type of Diaporthe eres (CBS 791.68).

Pathogenicity tests. There were no significant differences in lesion lengths between the two field trials in which seedlings were inoculated with fungal mycelia $(P=0.6325)$; therefore, data from both trials were combined. All isolates caused wood necrosis that developed upward and downward from the point of inoculation. Cadophora novi-eboraci, Cadophora spadicis, and Eutypa lata caused vascular discoloration that was significantly longer than control plants (Fig. 6). The mean lesion lengths were $54.9 \mathrm{~mm}$ for $\mathrm{Cado}$ phora novi-eboraci, $49.8 \mathrm{~mm}$ for Cadophora spadicis, and $41.5 \mathrm{~mm}$ for Eutypa lata. Although mean lesion lengths caused by Diaporthe eres $(24.0 \mathrm{~mm})$, Phaeoacremonium sicilianum (22.7 $\mathrm{mm})$, and Cryptovalsa ampelina $(22.1 \mathrm{~mm})$ were not significantly different from those caused by Cadophora novi-eboraci, Cadophora spadicis, and Eutypa lata, they also statistically overlapped with the control treatment $(8.2 \mathrm{~mm})$. Percent recovery on MEAS was $>80 \%$ for all treatments, and reisolated fungi were morphologically identical with those previously inoculated, thereby confirming Koch's postulates. None of these trunk disease pathogens were isolated from control plants.

\section{Discussion}

This study represents the first comprehensive characterization of trunk disease fungi recovered from wood of English walnut exhibiting typical symptoms of trunk diseases in Europe. Ten species belonging to five fungal families were isolated from black spots in

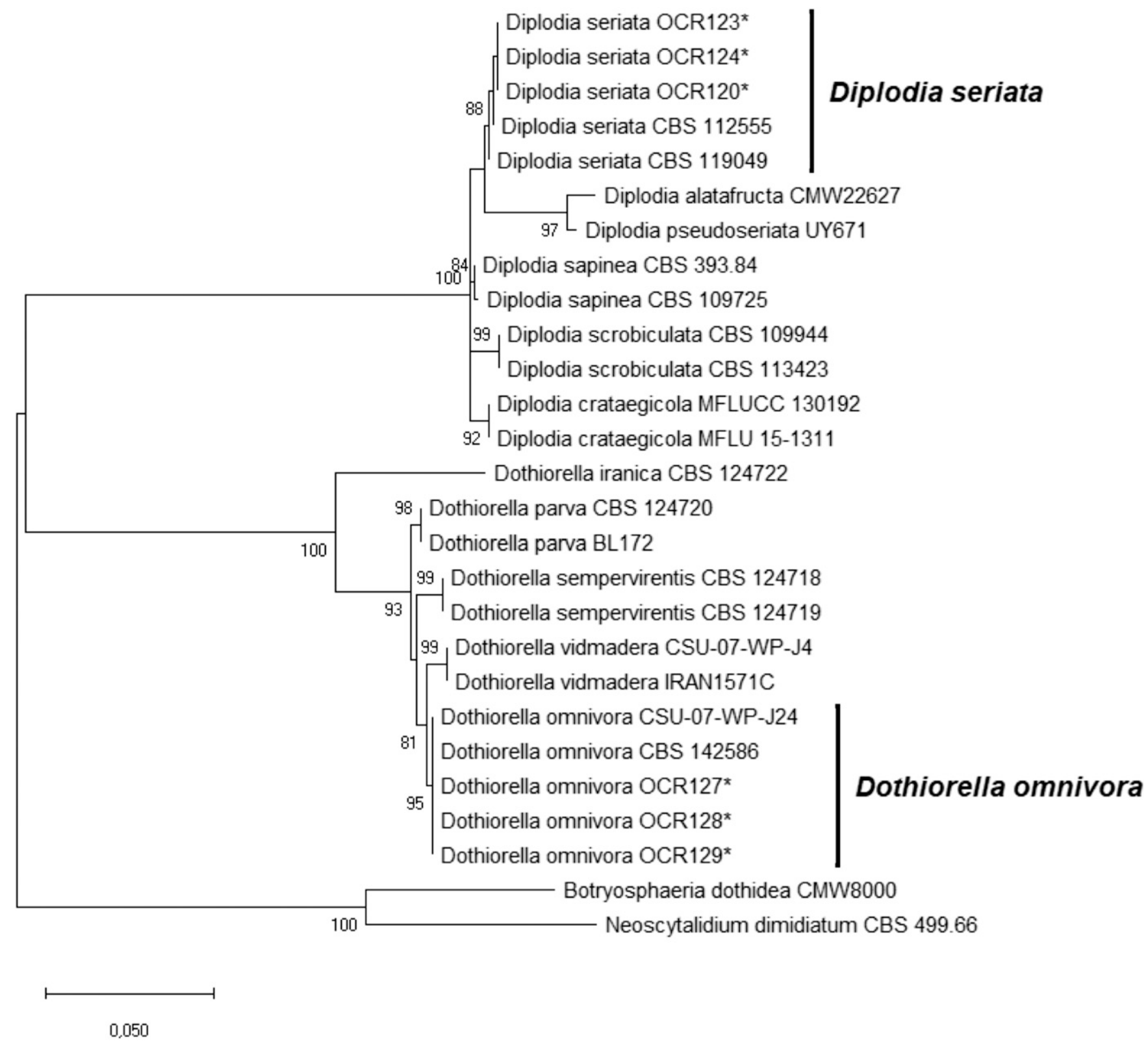

Fig. 5. Maximum likelihood phylogeny of Botryosphaeriaceae spp. as estimated from concatenated alignments of a two-gene data set (internal transcribed spacer and translation elongation factor $1-\alpha$ ). Maximum likelihood bootstrap percentages are indicated at the nodes. Support values $<70 \%$ bootstrap are omitted. The scale bar indicates 0.05 expected changes per site. Fungal species isolated in this study are indicated with an asterisk. 
the xylem vessels, as well as central, irregular, and wedge-shaped necrosis. Different fungal species often co-occurred in a single symptom, highlighting the complexity of the etiology of the symptoms observed.

The most predominant fungal taxa isolated from symptomatic wood of English walnut in this study belonged to the genus Cadophora. Species of Cadophora are involved in Petri disease and esca, which occur on young and mature grapevines, respectively, and are caused by a complex of fungi, often including Phaeomoniella chlamydospora and multiple species of Phaeoacremonium (Gramaje et al. 2018). Two Cadophora species, namely, Cadophora novieboraci and Cadophora spadicis, were associated mainly with two wood lesion types: black spots in the xylem vessels and central necrosis. These fungal species were described by Travadon et al. (2015), based on isolates collected from wood cankers or discolored wood of grapevine in North America and from previously misidentified Cadophora spp. isolates associated with discolored wood of kiwi fruit trees in Italy (Di Marco et al. 2004; Prodi et al. 2008). Cadophora novi-eboraci was isolated from necrotic wood of Malus domestica L. in Germany in 2017 (Gierl and Fischer 2017). The relationship between environmental conditions and Cadophora spp. distribution has been suggested by Blanchette et al. (2010) and Travadon et al. (2015). Cadophora luteo-olivacea has been mainly isolated from the warm, Mediterranean climate found in California (Rooney-Latham 2005; Travadon et al. 2015), South Africa
(Gramaje et al. 2014; Halleen et al. 2007), and Spain (Gramaje et al. 2011). By contrast, other species that have been isolated from cooler climates, such as Cadophora malorum in Antarctica (Blanchette et al. 2010) or Cadophora novi-eboraci in New York (Travadon et al. 2015), Germany (Gierl and Fischer 2017) and the Czech Republic (Eichmeier et al. 2018), might then be better adapted to them. This study represents the first record of Cadophora novi-eboraci and Cadophora spadicis on English walnut worldwide.

Botryosphaeriaceae and Diatrypaceae species were the second most predominant groups of fungi associated with three types of wood necrosis of English walnut in this study. Two Botryosphaeriaceae spp. were identified: namely, Diplodia seriata and Dothiorella omnivora. The role of Botryosphaeriaceae species as pathogens causing stem cankers and twig and branch dieback in English walnut has been extensively studied in California, with the description of up to 10 species belonging to six genera (Chen et al. 2013, 2014; Inderbitzin et al. 2010). Diplodia seriata has been isolated in affected English walnut trees in California (Chen et al. 2014) and China (Zhang et al. 2017). The low incidence of Diplodia seriata in our study agrees with the results of Inderbitzin et al. (2010) from peach and almond trees in California, Gramaje et al. (2012) from almond trees in Spain, Moyo et al. (2016) from persimmon trees in South Africa, and Panahandeh et al. (2019) from Syzygium cumini (L.) Skeels in Iran. In contrast, this species was the dominant Botryosphaeriaceae species on stone and pome fruit trees in several studies carried out in South

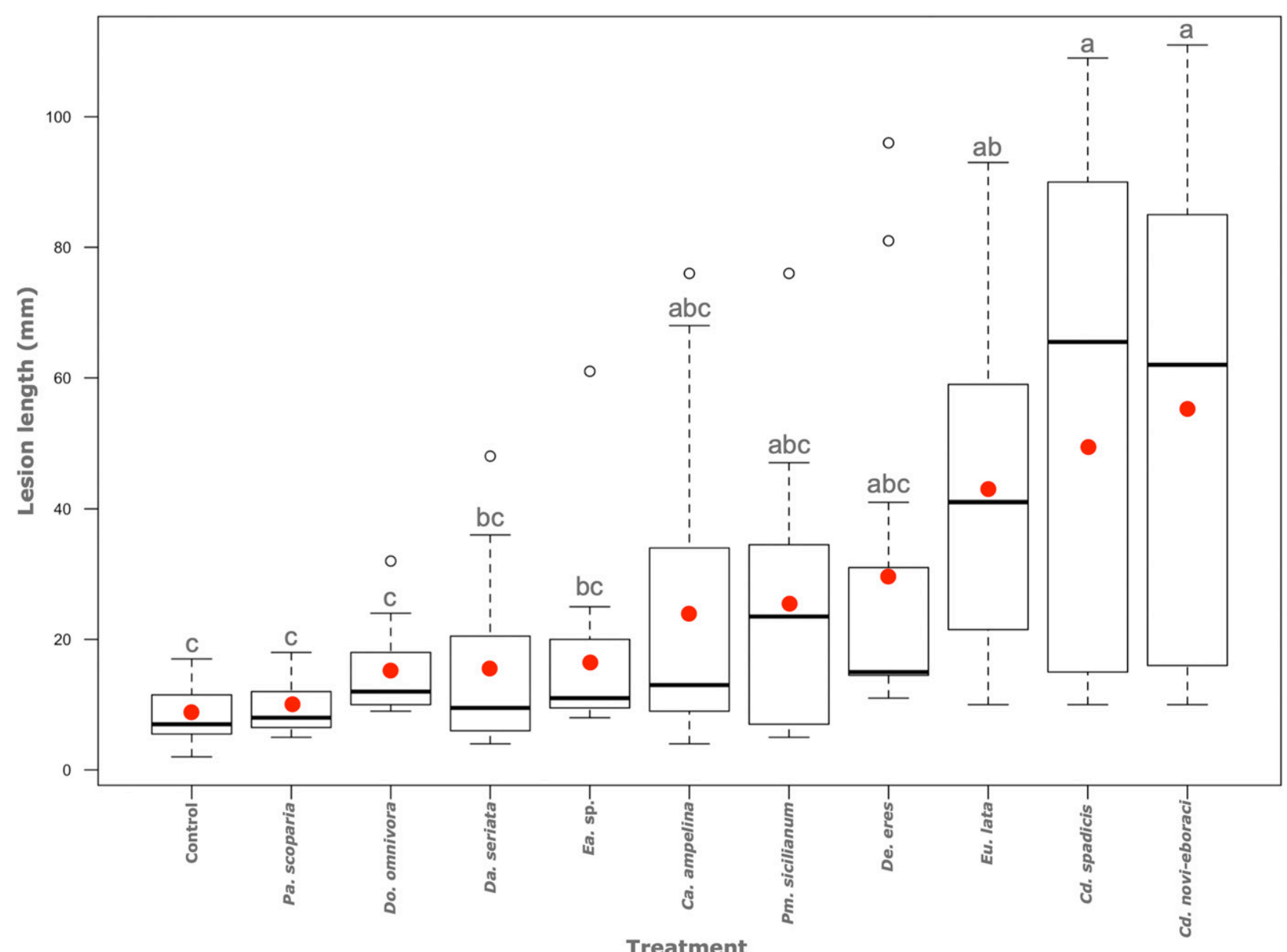

Treatment

Fig. 6. Box plots illustrating the distribution of the length of wood discoloration measured in walnut trees at 6 months after inoculations with 10 fungal species. Results are ordered according to the mean. Solid lines and circles within the boxes correspond to the median and the mean, respectively. The top and bottom lines of the box correspond to the 25th and 75th percentiles of the data, respectively. Error bars represent the 10th and 90th percentiles, and circles represent the fifth and 95th percentiles. Mean lengths of wood discoloration of walnut trees with different letters are significantly different at $P<0.05$ (Tukey test). $P a .=$ Peroneutypa, Do. $=$ Dothiorella, Da. $=$ Diplodia, Ea. $=$ Eutypella, Ca. $=$ Cryptovalsa, $P m .=$ Phaeoacremonium, De. $=$ Diaporthe, Eu. $=$ Eutypa, and Cd. $=$ Cadophora. 
Africa (Cloete et al. 2011; Damm et al. 2007; Slippers et al. 2007). Dothiorella omnivora affecting walnut trees in France and Iran was reported in 2016 (Linaldeddu et al. 2016). Other hosts for this species include grapevine in Hungary (Váczy et al. 2018) and Australia (Linaldeddu et al. 2016), hazelnut and the European hophornbeam in Italy (Linaldeddu et al. 2016), the northern whitecedar and the Lawson cypress in Serbia (Linaldeddu et al. 2016), and dogwood in Italy (Dissanayake et al. 2017).

The majority of walnut isolates in the Diatrypaceae family belonged to Eutypa lata, whereas a minority of isolates were Cryptovalsa ampelina, Eutypella sp., and Peroneutypa scoparia. Studies of Diatrypaceae spp. on English walnut are scarce, as only Eutypa lata and Cryptovalsa ampelina have been reported to affect this crop in Greece (Rumbos 1988) and California (Trouillas et al. 2010), respectively. To the authors' knowledge, Eutypella sp. and Peroneutypa scoparia have not been reported on English walnut before this study. Thus, this is the first report of Eutypella sp. and Peroneutypa scoparia on English walnut worldwide. Members of the family Diatrypaceae are widespread globally, but the involvement of up to 17 species of this family in cankers and wood necrosis of grapevines worldwide led to researchers' interest in studying them (Moyo et al. 2018). In the Czech Republic, Eutypella lata is considered the most common species associated with grapevine trunk diseases (Baránek et al. 2018). The overlap of Diatrypaceae spp. between vineyards and natural ecosystems was demonstrated in South Africa in 2019 (Moyo et al. 2019).

Additional fungal trunk pathogens isolated in low numbers in this study include fungi belonging to the families Diaporthaceae (Diaporthe eres) and Togniniaceae (Phaeoacremonium sicilianum). The species criterion concept in the Diaporthe eres complex was revised in 2018 based on a multilocus sequence approach (Fan et al. 2018). Diaporthe eres has often been reported as a plant pathogen in a wide range of woody hosts, including English walnut in China (Fan et al. 2018; Yang et al. 2018) and Italy (Gomes et al. 2013). Phaeoacremonium sicilianum was recorded on Juglans sp. in South Africa in 2018 (Spies et al. 2018). Other additional hosts for this species include fig in South Africa (Spies et al. 2018); grapevine in Italy (Essakhi et al. 2008), South Africa (Spies et al. 2018; White et al. 2011), and Spain (Gramaje et al. 2009); and olive in Italy (Carlucci et al. 2015).

Results of the field pathogenicity test showed significant differences in the degree of virulence among fungal species inoculated into English walnut woody stems. Of the 10 inoculated species, Cadophora novi-eboraci, Cadophora spadicis, and Eutypa lata caused lesions significantly longer than the control. Cadophora spp. have been traditionally considered as slow colonizing fungi in several pathogenicity tests conducted on grapevine (Navarrete et al. 2011; Travadon et al. 2015; Úrbez-Torres et al. 2014). In particular, Cadophora novi-eboraci caused wood discoloration in young vines ranging from 1.5 to $2.6 \mathrm{~cm}$ after a long 24-month incubation period in California (Travadon et al. 2015). In contrast, Cadophora luteoolivacea produced lesions of up to $4.4 \mathrm{~cm}$ in grapevine trunks after 14 months of incubation under field conditions in South Africa (Halleen et al. 2007), or up to $9.2 \mathrm{~cm}$ in grapevine rootstock cuttings after 14 weeks of incubation under controlled conditions in Spain (Gramaje et al. 2011). Although a wide degree of variability in lesion development was found among individual trees, species of Cadophora were shown to be highly virulent in English walnut in the Czech Republic, with necrosis reaching up to $11.1 \mathrm{~cm}$ after 6 months of incubation under field conditions. This finding, along with the high frequency of Cadophora spp. isolates collected from affected trees, demonstrates that English walnut should be considered as a susceptible host for these fungi. Inoculation tests with Eutypa lata on walnut also yielded characteristic disease cankers significantly longer than the control in Greece (Rumbos 1988). It is interesting to note that other species considered as pathogens in other woody hosts, such as Peroneutypa scoparia on kiwifruit in Chile (Castilla-Cayuman et al. 2019) or Dothiorella omnivora, Cryptovalsa ampelina, and Phaeoacremonium sicilianum on grapevine in Hungary (Váczy et al. 2018), California (Trouillas and Gubler
2010) and Spain (Gramaje et al. 2009), respectively, produced short lesions in inoculated English walnut trees in the present study. Conflicting reports on the virulence of several fungal trunk pathogens exist in the literature. For example, Diplodia seriata was also considered a weak pathogen on walnut (Chen et al. 2014), as well as on other woody hosts such as olive (Moral et al. 2010) or grapevine (Úrbez-Torres and Gubler 2009). However, other studies have confirmed the pathogenicity of this fungal species by artificial inoculation on grapevine (Auger et al. 2004; Rovesti and Montermini 1987; van Niekerk et al. 2006). Elena et al. (2015) proved the existence of different virulence levels in this fungal species on grapevine. Cryptovalsa ampelina has also been classified as weakly pathogenic based on the relatively short canker extension after grapevine inoculations in Spain (Luque et al. 2006). In the case of Cryptovalsa ampelina, the low frequencies of both mycelium reisolation and wound canker extension on grapevines suggested a low virulence for this fungus in Spain (Luque et al. 2006), compared with the significant dark brown stem discoloration caused by the pathogen in South Africa (Mostert et al. 2004).

The information obtained from this research provides the local walnut industry with knowledge on the occurrence of fungal trunk disease pathogens and forms a baseline for further research in this pathosystem worldwide.

\section{Acknowledgment}

We acknowledge E. Penazova for technical assistance.

\section{Literature Cited}

Agustí-Brisach, C., Moral, J., Felts, D., Trapero, A., and Michailides, T. J. 2019. Interaction between Diaporthe rushicola and Neofusicoccum mediterraneum causing branch dieback and fruit blight of English walnut in California, and effect of pruning wounds to the infection. Plant Dis. 103:1196-1205.

Alves, A., Crous, P. W., Correia, A., and Phillips, A. J. L. 2008. Morphological and molecular data reveal cryptic speciation in Lasiodiplodia theobromae. Fungal Divers. 28:1-13.

Auger, J., Esterio, M., Ricke, G., and Pérez, I. 2004. Black dead arm and basal canker of Vitis vinifera cv. Red Globe caused by Botryosphaeria obtusa in Chile. Plant Dis. 88:1286.

Avanzato, D., McGranahan, G. H., Vahdati, K., Botu, M., Iannamico, L., and Assche, J. V., eds. 2014. Following Walnut Footprints (Juglans regia L.): Cultivation and Culture, Folklore and History, Traditions and Uses. International Society for Horticultural Science, Leuven, Belgium.

Badenes, M. L., and Byrne, D. H., eds. 2012. Fruit Breeding, vol. 8. Springer Science and Business Media, Boston, MA.

Baránek, M., Armengol, J., Pecenka, J., Calzarano, F., Penazova, E., Vachun, M., and Eichmeier, A. 2018. Incidence of symptoms and fungal pathogens associated with grapevine trunk diseases in Czech vineyards: First example from a north-eastern European grape-growing regions. Phytopathol. Mediterr. 57:449-458.

Blanchette, R. A., Held, B. W., Arenz, B. E., Jurgens, J. A., Baltes, N. J., Duncan, S. M., and Farrell, R. L. 2010. An Antarctic hot spot for fungi at Shackleton's historic hut on Cape Royds. Microb. Ecol. 60:29-38.

Box, G. E. P., Hunter, W. G., and Hunter, J. S. 1978. Statistics for Experimenters: An Introduction to Design, Data Analysis, and Model Building. John Wiley and Sons, New York, NY.

Carbone, I., and Kohn, L. M. 1999. A method for designing primer sets for speciation studies in filamentous ascomycetes. Mycologia 91:553-556.

Carlucci, A., Lops, F., Cibelli, F., and Raimondo, M. L. 2015. Phaeoacremonium species associated with olive wilt and decline in southern Italy. Eur. J. Plant Pathol. 141:717-729.

Castilla-Cayuman, A., Lolas, M., and Díaz, G. A. 2019. First report of Peroneutypa scoparia causing cane dieback in kiwifruit in Chile. Plant Dis. 103:373.

Chen, S. F., Fichtner, E., Morgan, D. P., and Michailides, T. J. 2013. First report of Lasiodiplodia citricola and Neoscytalidium dimidiatum causing death of graft union of English walnut in California. Plant Dis. 97:993.

Chen, S. F., Morgan, D. P., Hasey, J. K., Anderson, K., and Michailides, T. J. 2014. Phylogeny, morphology, distribution, and pathogenicity of Botryosphaeriaceae and Diaporthaceae from English walnut in California. Plant Dis. 98:636-652.

Cloete, M., Fourie, P. H., Damm, U., Crous, P. W., and Mostert, L. 2011. Fungi associated with die-back symptoms of apple and pear trees, a possible inoculum source of grapevine trunk disease pathogens. Phytopathol. Mediterr. 50:S176-S190.

Crous, P. W., Gams, W., Stalpers, J. A., Robert, V., and Stegehuis, G. 2004 MycoBank: An online initiative to launch mycology into the 21 st century. Stud. Mycol. 50:19-22. 
Damm, U., Crous, P. W., and Fourie, P. H. 2007. Botryosphaeriaceae as potential pathogens of Prunus species in South Africa, with descriptions of Diplodia africana and Lasiodiplodia plurivora sp. nov. Mycologia 99:664-680.

Darriba, D., Taboada, G. L., Doallo, R., and Posada, D. 2012. jModelTest 2: More models, new heuristics and parallel computing. Nat. Methods 9:772.

Dervis, S., Turkolmez, S., Cifci, O., Ulubas-Serce, C., and Dikilitas, M. 2019. First report of Neoscytalidium dimidiatum causing black canker and root to of walnut in Turkey. Plant Dis. 103:2129.

Di Marco, S., Calzarano, F., Osti, F., and Mazzullo, A. 2004. Pathogenicity of fungi associated with a decay of kiwifruit. Aus. Plant Pathol. 33:337-342.

Díaz, G. A., Latorre, B. A., Ferrada, E., Gutiérrez, M., Bravo, F., and Lolas, M. 2018. First report of Diplodia mutila causing branch dieback of English walnut cv. Chnadler in the Maule Region, Chile. Plant Dis. 102:1451.

Dissanayake, A. J., Camporesi, E., Hyde, K. D., Yan, J. Y., and Li, X. H. 2017. Saprobic Botryosphaeriaceae, including Dothiorella italica sp. nov., associated with urban and forest trees in Italy. Mycosphere 8:1157-1176.

Eichmeier, A., Baranek, M., and Pidra, M. 2010. Analysis of genetic diversity and phylogeny of partial coat protein domain in Czech and Italian GFLV isolates. Plant Prot. Sci. 46:145-148.

Eichmeier, A., Pečenka, J., Peňázová, E., Baránek, M., Català-García, S., León, M., Armengol, J., and Gramaje, D. 2018. High-throughput amplicon sequencing-based analysis of active fungal communities inhabiting grapevine after hot-water treatments reveals unexpectedly high fungal diversity. Fungal Ecol. 36:26-38.

Elena, G., García-Figueres, F., Reigada, S., and Luque, J. 2015. Intraspecific variation in Diplodia seriata isolates occurring on grapevines in Spain. Plant Pathol. 64:680-689.

English, H., and Davis, I. R. 1978. Eutypa armeniacae in apricot: Pathogenesis and induction of xylem soft rot. Hilgardia 46:193-204.

Essakhi, S., Mugnai, L., Crous, P. W., Groenewald, J. Z., and Surico, G. 2008. Molecular and phenotypic characterisation of novel Phaeoacremonium species isolated from esca diseased grapevines. Persoonia 21:119-134.

Fan, X., Hyde, K. D., Liu, M., Liang, Y., and Tian, C. 2015. Cytospora species associated with walnut canker disease in China, with description of a new species C. gigalocus. Fungal Biol. 119:310-319.

Fan, X., Yang, Q., Bezerra, J. D. P., Alvarez, L. V., and Tian, C. 2018. Diaporthe from walnut tree (Juglas regia) in China, with insight of the Diaporthe eres complex. Mycol. Prog. 17:841-853.

FAO. 2018. Statistical databases. Food and Agriculture Organization of the United Nations. http://www.fao.org/home/en/

Gierl, L., and Fischer, M. 2017. Grapevine trunk disease in German viticulture II. Associated fungi occurring in non-Vitis hosts, and first report of Phaeoacremonium angustius. Vitis 56:103-110.

Glass, N. L., and Donaldson, G. C. 1995. Development of primer sets designed for use with the PCR to amplify conserved genes from filamentous infection due to Phaeoacremonium spp. J. Clin. Microbiol. 41:1332-1336.

Glawe, D. A., and Rogers, J. D. 1984. Diatrypaceae in the Pacific Northwest. Mycotaxon 20:401-460.

Gomes, R. R., Glienke, C., Videira, S. I. R., Lombard, L., Groenewald, J. Z., and Crous, P. W. 2013. Diaporthe: A genus of endophytic, saprobic and plant pathogenic fungi. Persoonia 31:1-41.

Gramaje, D., Agustí-Brisach, C., Pérez-Sierra, A., Moralejo, E., Olmo, D., Mostert, L., Damm, U., and Armengol, J. 2012. Fungal trunk pathogens associated with wood decay of almond trees on Mallorca (Spain). Persoonia 28:1-13.

Gramaje, D., Armengol, J., Colino, M. I., Santiago, R., Moralejo, E., Olmo, D., Luque, L., and Mostert, L. 2009. First report of Phaeoacremonium inflatipes, $P$. iranianum, and $P$. sicilianum causing Petri disease of grapevine in Spain. Plant Dis. 93:964

Gramaje, D., Baumgartner, K., Halleen, F., Mostert, L., Sosnowski, M. R., ÚrbezTorres, J. R., and Armengol, J. 2016. Fungal trunk diseases: A problem beyond grapevines? Plant Pathol. 65:355-356.

Gramaje, D., León, M., Santana, M., Crous, P. W., and Armengol, J. 2014. Multilocus ISSR markers reveal two major genetic groups in Spanish and South African populations of the grapevine fungal pathogen Cadophora luteo-olivacea. PLoS One 9:e110417.

Gramaje, D., Mostert, L., and Armengol, J. 2011. Characterization of Cadophora luteo-olivacea and $C$. melinii isolates obtained from grapevines and environmental samples from grapevine nurseries in Spain. Phytopathol. Mediterr. 50:S112-S126.

Gramaje, D., Úrbez-Torres, J. R., and Sosnowski, M. R. 2018. Managing grapevine trunk diseases with respect to etiology and epidemiology: Current strategies and future prospects. Plant Dis. 102:12-39.

Guarnaccia, V., Groenewald, J. Z., Woodhall, J., Armengol, J., Cinelli, T., Eichmeier, A., Ezra, D., Fontaine, F., Gramaje, D., Gutierrez-Aguirregabiria, A., Kaliterna, J., Kiss, L., Larignon, P., Luque, J., Mugnai, L., Naor, V., Raposo, R., Sándor, E., Váczy, K. Z., and Crous, P. W. 2018. Diaporthe diversity and pathogenicity revealed from a broad survey of grapevine diseases in Europe. Persoonia 40:135-153.

Halleen, F., Mostert, L., and Crous, P. W. 2007. Pathogenicity testing of lesserknown vascular fungi of grapevines. Australas. Plant Pathol. 36:277-285.

Harrington, T. C., and McNew, D. L. 2003. Phylogenetic analysis places the Phialophora-like anamorph genus Cadophora in the Helotiales. Mycotaxon 87:141-151.
Inderbitzin, P., Bostock, R. M., Trouillas, F. P., and Michailides, T. J. 2010. A six locus phylogeny reveals high species diversity in Botryosphaeriaceae from California almond. Mycologia 102:1350-1368.

Katoh, K., and Toh, H. 2008. Recent developments in the MAFFT multiple sequence alignment program. Brief. Bioinform. 9:286-298.

Li, G. Q., Liu, F. F., Li, J. Q., Liu, Q. L., and Chen, S. F. 2015. Characterization of Botryosphaeria dothidea and Lasiodiplodia pseudotheobromae from English walnut in China. J. Phytopathol. 164:348-353.

Linaldeddu, B. T., Deidda, A., Scanu, B., Franceschini, A., Alves, A. Abdollahzadeh, J., and Phillips, A. J. L. 2016. Phylogeny, morphology and pathogenicity of Botryosphaeriaceae, Diatrypaceae and Gnomoniaceae associated with branch diseases of hazelnut in Sardinia (Italy). Eur. J. Plant Pathol. 146:259-279.

Luque, J., Sierra, D., Torres, E., and García, F. 2006. Cryptovalsa ampelina on grapevines in N.E. Spain: Identification and pathogenicity. Phytopathol. Mediterr. 45:S101-S109.

Makatini, G. J. 2014. The Role of Sucker Wounds as Portals for Grapevine Trunk Pathogen Infections. Master's thesis. Stellenbosch University, Matieland, South Africa.

Marin-Felix, Y., Hernández-Restrepo, M., Wingfield, M. J., Akulov, A., Carnegie, A. J., Cheewangkoon, R., Gramaje, D., Groenewald, J. Z., Guarnaccia, V., Halleen, F., Lombard, L., Luangsa-ard, J., Marincowitz, S., Moslemi, A., Mostert, L., Quaedvlieg, W., Schumacher, R. K., Spies, C. F. J., Thangavel, R., Taylor, P. W. J., Wilson, A. M., Wingfield, B. D., Wood, A. R., and Crous, P. W. 2019. Genera of phytopathogenic fungi: GOPHY 2. Stud. Mycol. 92:47-133.

Meng, L., Yu, C., and Li, G. 2018. First report of Diaporthe amygdali causing walnut twig canker in Shandong Province of China. Plant Dis. 102:1859.

Moral, J., Muñoz-Díez, C., González, N., Trapero, A., and Michailides, T. J. 2010 Characterization and pathogenicity of Botryosphaeriaceae species collected from olives and other hosts in Spain and California. Phytopathology 100: 1340-1351.

Mostert, L., Halleen, F., Creaser, M. L., and Crous, P. W. 2004. Cryptovalsa ampelina, a forgotten shoot and cane pathogen of grapevines. Aus. Plant Pathol. 33:295-299.

Moyo, P., Allsopp, E., Roets, F., Mostert, L., and Halleen, F. 2014. Arthropods vector trunk disease pathogens. Phytopathology 104:1063-1069.

Moyo, P., Mostert, L., Bester, M., and Halleen, F. 2016. Trunk disease fung associated with Diospyros kaki in South Africa. Plant Dis. 100:2383-2393.

Moyo, P., Mostert, L., and Halleen, F. 2019. Diatrypaceae species overlap between vineyards and natural ecosystems in South Africa. Fungal Ecol. 39: 142-151.

Moyo, P., Mostert, L., Spies, C. F. J., Damm, U., and Halleen, F. 2018. Diversity of Diatrypaceae species associated with dieback of grapevines in South Africa, with the description of Eutypa cremea sp. nov. Plant Dis. 102:220-230.

Navarrete, F., Abreo, E., Martínez, S., Bettucci, L., and Sandra, L. 2011. Pathogenicity and molecular detection of Uruguayan isolates of Greeneria uvicola and Cadophora luteo-olivacea associated with grapevine trunk diseases. Phytopathol. Mediterr. 50:166-175.

O’Donnell, K., and Cigelnik, E. 1997. Two divergent intragenomic rDNA ITS2 types within a monophyletic lineage of the fungus Fusarium are nonorthologous. Mol. Phylogenet. Evol. 7:103-116.

Panahandeh, S., Mohammadi, H., and Gramaje, D. 2019. Trunk disease fungi associated with Syzgium cumini in Iran. Plant Dis. 103:711-720.

Phillips, A. J. L., Alves, A., Abdollahzadeh, J., Slippers, B., Wingfield, M. J., Groenewald, J. Z., and Crous, P. W. 2013. The Botryosphaeriaceae: Genera and species known from culture. Stud. Mycol. 76:51-167.

Prodi, A., Sandalo, S., Tonti, S., Nipoti, P., and Pisi, A. 2008. Phialophora-like fungi associated with kiwifruit elephantiasis. J. Plant Pathol. 90:487-494.

Rambaut, A. 2002. SE-AL version 2.0a11: Sequence alignment program. http:// tree.bio.ed.ac.uk/software/seal/

Rooney-Latham, S. 2005. Etiology, Epidemiology and Pathogen Biology of Esca Disease of Grapevines in California. Publication no. AAT 3191148. Ph.D. dissertation, University of California, Davis.

Rovesti, L., and Montermini, A. 1987. Un deperimento della vite causato da Sphaeropsis malorum diffuso in provincia di Reggio Emilia. Inf. Fitopatol. 37:59-61.

Rumbos, I. C. 1988. Isolation of Eutypa lata from Juglans regia, and pathogenicity studies on different wood plants. J. Phytopathol. 122:193-199.

Senwanna, C., Phookamsak, R., Doilom, M., Hyde, K. D., and Cheewangkoon, R. 2017. Novel taxa of Diatrypaceae from Para rubber (Hevea brasiliensis) in northern Thailand; introducing a novel genus Allocryptovalsa. Mycosphere 8: $1835-1855$

Slippers, B., Smit, W. A., Crous, P. W., Coutinho, T. A., Wingfield, B. D., and Wingfield, M. J. 2007. Taxonomy, phylogeny and identification of Botryosphaeriaceae associated with pome and stone fruit trees in South African and other regions of the world. Plant Pathol. 56:128-139.

Spies, C. F. J., Moyo, P., Halleen, F., and Mostert, L. 2018. Phaeoacremonium species diversity on woody hosts in the Western Cape Province of South Africa. Persoonia 40:26-62.

Tamura, K., Stecher, G., Peterson, D., Filipski, A., and Kumar, S. 2013. MEGA6: Molecular Evolutionary Genetics Analysis version 6.0. Mol. Biol. Evol. 30 $2725-2729$ 
Travadon, R., Lawrence, D. P., Rooney-Latham, S., Gubler, W. D., Wilcox, W. F., Rolshausen, P. E., and Baumgartner, K. 2015. Cadophora species associated with wood-decay of grapevine in North America. Fungal Biol. 119:53-66.

Trouillas, F. P., and Gubler, W. D. 2010. Pathogenicity of Diatrypaceae species in grapevine in California. Plant Dis. 94:867-872.

Trouillas, F. P., Úrbez-Torres, J. R., and Gubler, W. D. 2010. Diversity of diatrypaceous fungi associated with grapevine canker diseases in California. Mycologia 102:319-336.

Úrbez-Torres, J. R., and Gubler, W. D. 2009. Pathogenicity of Botryosphaeriaceae spp. isolated from grapevine cankers in California. Plant Dis. 93:584-592.

Úrbez-Torres, J. R., Haag, P., Bowen, P., and O'Gorman, D. T. 2014. Grapevine trunk diseases in British Columbia: Incidence and characterization of the fungal pathogens associated with esca and Petri diseases of grapevine. Plant Dis. 98: 456-468.

Váczy, K. Z., Németh, M. Z., Csikós, A., Kovács, G. M., and Kiss, L. 2018. Dothiorella omnivora isolated from grapevine with trunk disease symptoms in Hungary. Eur. J. Plant Pathol. 150:817-824.

van Niekerk, J. M., Fourie, P. H., Halleen, F., and Crous, P. W. 2006. Botryosphaeria spp. as grapevine trunk disease pathogens. Phytopathol. Mediterr. 45: S43-S54. van Niekerk, J. M., Halleen, F., and Fourie, P. H. 2011. Temporal susceptibility of grapevine pruning wounds to trunk pathogen infection in South African grapevines. Phytopathol. Mediterr. 50(Suppl):S139-S150.

White, C. L., Halleen, F., Fischer, M., and Mostert, L. 2011. Characterisation of the fungi associated with esca diseased grapevines in South Africa. Phytopathol. Mediterr. 50:S204-S223.

White, T. J., Bruns, T., Lee, S., and Taylor, J. 1990. Amplification and direct sequencing of fungi ribosomal RNA genes for phylogenetics. Pages 315-322 in: PCR Protocols: A Guide to Methods and Applications. M. A. Innis, D. H. Gelfand, J. J. Sninsky, and T. J. White, eds. Academic Press, San Diego, CA.

Yang, Q., Fan, X.-L., Guarnaccia, V., and Tian, C.-M. 2018. High diversity of Diaporthe species associated with dieback diseases in China, with twelve new species described. MycoKeys 39:97-149.

Zhang, M., Zhang, Y. K., Geng, Y. H., Zang, R., and Wu, H. Y. 2017. First report of Diplodia seriata causing twig dieback of English walnut in China. Plant Dis. 101:1036.

Zhao, S. F., Guo, K. F., and Yiming, A. 2018. First report of Cytospora nivea causing Cytospora canker on walnut (Juglans regia L.) in the Tianshan mountains region of Xinjiang, China. Plant Dis. 102:2640. 